CPE

4,2

Received 8 November 2021 Revised 8 November 2021 Accepted 8 November 2021

\section{Research on the threshold of symbiosis between finance and real economy-empirical test based on banking panel threshold model}

\author{
Conglai Fan, Xinlei Cai and Jian Lin \\ Yangtze River Delta Economics and Social Development Research Center, \\ Nanjing University, Nanjing, China
}

\begin{abstract}
Purpose - Starting from the theoretical mechanism of profit sharing between finance and the real economy, this paper reviews and analyzes the profitability of China's banking industry and makes a horizontal comparison with the banking industry of the United States, Japan, and Germany.

Design/methodology/approach - Based on the panel threshold model, it is found that there is a dualthreshold asymmetric effect between banking profit and the growth of real economy. When the net profit rate of the banking industry is lower than $0.491 \%$, the increase in banking profitability will inhibit the growth of real economy due to profit grabbing; when the rate falls within the range of $0.491-0.801 \%$, the increase in bank profitability is conducive to the growth of real economy.

Findings - Finance and the real economy are in the most comfortable symbiotic state; when the rate is higher than $0.801 \%$, the continued increase in bank profitability will weaken the promotion effect of finance on the real economy, but bank profitability and the growth of real economy are still in a symbiotic state of positive promotion.

Originality/value - The promotion effect of China's bank profitability to the growth of real economy has shifted from the suboptimal state to the optimal range as a whole, which is attributed to the strong deleveraging and strict supervision of the Chinese government after 2016, the timely and decisive "stepping on the brakes", pulling the financial sector back from the "illusion" caused by "self-circulated" profits and preventing it from harming the real economy.
\end{abstract}

Keywords Banking profit, Real economy, Threshold effect, Reform path

Paper type Research paper

\section{Introduction}

Based on data from the China Banking and Insurance Regulatory Commission (CBIRC), China's banking industry achieved a cumulative net profit of over RMB2 trillion in 2020, with an average return of equity (ROE) of $8.94 \%$. Hit by the COVID-19 pandemic, more than 600 out of 3,800 A-share listed companies suffered losses in the first three-quarters of 2020. Since the pandemic began, calls for financial institutions to make interest concessions to the real economy have been growing, and policies on fee cuts and interest concessions have been implemented successively. Finance "back-feeding" the real economy has become an indisputable social fact and concerted action in the financial industry. From the data

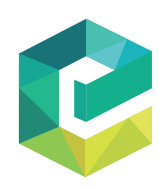

(C) Economist. Published in China Political Economy. Published by Emerald Publishing Limited. This article is published under the Creative Commons Attribution (CC BY 4.0) licence. Anyone may reproduce, distribute, translate and create derivative works of this article (for both commercial and noncommercial purposes), subject to full attribution to the original publication and authors. The full terms of this licence may be seen at http://creativecommons.org/licences/by/4.0/legalcode. Originally published in Simplified Chinese in Economist.

Funding: Major Research Project "Research on Basic Theoretical Issues of Economics with Chinese Characteristics in the New Era" of the National Social Science Fund of China (Grant No. 18vxk002). 
released by the regulatory authorities, China's financial institutions achieved the goal of making interest concessions worth RMB1.5 trillion to the real economy in 2020, where RMB590bn in profits was transferred by guiding the reduction of loan interest rates, accounting for nearly $40 \%$. The concerted effort of "making interest concession as much as possible" has also made some small and medium-sized banks feel the pressure of survival and development crises. The interest margin of commercial banks has continued to narrow, and the operation of different types of banking institutions is differentiated clearly. Large banks scramble for "funds", "customers" and "markets" based on their advantage in outlets, and local small and medium-sized ones are facing the dilemma of "asset shortage", "debt difficulties" and "high risks" in sustainable operation. On May 24, 2019, Baoshang Bank was jointly taken over by the People's Bank of China (PBC) and CBIRC due to serious credit risks. According to statistics, in 2020, there were seven cases of mergers and restructurings of small and medium-sized banks in various provinces in China, including Sichuan, Shanxi, Shaanxi and Henan, the highest number compared to the previous years. Furthermore, China's Government Work Report has also proposed "promoting small and medium-sized banks to replenish capital" for two consecutive years. On July 1, 2020, the executive meeting of the State Council proposed to replenish bank capital through special bonds for the first time and confirmed that "a certain amount should be arranged in the new special bond limit of local governments this year. Local governments were allowed to explore methods to replenish small and medium-sized banks' capital, including subscribing convertible bonds." Subsequently, the CBIRC and other five ministries or commissions promulgated the Work Plan for Deepening Reform and Replenishing the Capital of Small and Medium-sized Banks. At least six provinces, i.e., Guangdong, Shanxi, Zhejiang, Guangxi, Inner Mongolia and Sichuan, have issued special bonds to support small and medium-sized banks in replenishing capital, with a total amount of RMB62 bn.

Article 16 of the Proposals of the CPC Central Committee for Formulating the 14th FiveYear Plan (2021-2025) for National Economic and Social Development and the Long-range Objectives Through the Year 2035 proposes to "drive the balanced development of the financial sector and real estate industry with the real economy". The connotation of balanced development emphasizes the mutual benefit and symbiosis of the financial sector and the real economy. The financial sector shall neither seek nothing but profits and grab the profits of the real economy excessively nor shall it always be a good Samaritan with acts of charity and endanger the foundation of its own survival and growth. As the principal force of the financial sector, the banking industry is the main valve for regulating the distribution of financial resources. Currently, the assets and profits of China's banking industry account for $90 \%$ of the total assets and profits of the financial sector. In research on the relationship between the financial sector and the development of the real economy, the banking industry represents a typical sample of financial reform. Under this background, studying the relationship between China's financial sector and the real economy systematically from the perspective of the banking industry and measuring the reasonable profitability threshold of the banking industry is of great significance for driving the balanced development of China's economy and financial sector and the high-quality reform and growth of the financial sector. Studies suggest that there is a nonlinear dual-threshold relationship between the profitability of the banking industry and the growth of the real economy. That is, when the banking net profit rate is lower than $0.491 \%$, the increase in bank profitability will inhibit the growth of real economy; when the rate falls within the range of $0.491-0.801 \%$, the increase in bank profitability is conducive to the growth of real economy; when the rate is higher than $0.801 \%$, the continued increase in bank profitability will weaken the promotion effect of finance on the real economy. Currently, the profitability of China's banking industry contributes positively to the real economy in general. If the Chinese government had not strongly deleveraged, strictly regulated and decisively "put the brakes on" in a timely manner after 2016, the
Threshold of symbiosis 
CPE

4,2

148

banking industry would have slid to the brink of harming the real economy, and the consequences would have been unimaginable.

This study is innovative in two aspects. On the one hand, it has provided further empirical support for the nonlinear relationship between the profitability of the banking industry and the growth of the real economy and estimated the threshold between them, offering a theoretical basis for policy formulation. On the other hand, different from previous studies focusing on the view that excessively high profitability of the banking industry harmed the real economy, this study indicates that the excessively low-profit level of banking profitability also has a negative influence on the real economy, which should arouse the attention of decision makers.

\section{Literature review}

The theory of financial development and the reality of financial evolution have fully demonstrated that "finance supports the economy as the blood supply of body" - the real economy is the source of profitability of the financial sector, and the development of the financial sector positively facilitates the growth of the real economy. But in fact, the relationship between finance and real economy, rather than a simple linear relationship, has systemic complexity: On the one hand, the growth of the financial sector can promote the real economy from the perspective of financial market functions and policy practice. On the other hand, the financial sector may rely on information advantages and operational convenience to encroach on the profits of the real economy for its own benefits, and excessive profitability of the banking industry can harm potential economic growth. As a result, the excessive profitability of the banking industry can damage potential economic growth. Based on this logic, the existing studies can be roughly divided into three categories:

(1) The view that the financial sector stimulates the real economy. According to traditional monetary and financial theories, finance is a medium for the operation of the commodity economy and plays a role in allocating resources. It has long been a mainstream consensus in academia that finance can promote economic development (Levine, 1991; Greenwood and Smith, 1997; Heblich and Trew, 2019). From Schumpeter (1982), economists began to recognize and emphasize the significance of the financial system to the release of entrepreneurship and economic development. The study by Bagehot (1873) emphasized the essential role of the banking system in economic development, and Bagehot believed that banks could encourage innovation by identifying and raising funds, thereby improving the technological level and driving economic growth. Goldsmith (1969) and Shaw (1973) thought that the financial system played a crucial role in economic growth, and financial development could further boost economic growth by promoting savings. Massive literature represented by King and Levine (1993) confirmed the role of financial development in driving long-term economic growth based on the transnational linear measurement method. Many domestic studies also stated that the financial sector could improve the efficiency of the real economy with conclusive empirical evidence (Chen and Zhao, 2012; Jiang and Liu, 2012). Based on the above analysis, we proposed Hypothesis 1:

H1. The development of the banking industry has a positive influence on the growth of the real economy; that is, the more profitable the banking industry, the faster the growth of the real economy.

(2) The view that the financial sector grabs the profits of the real economy. According to this view, the financial sector, which is supposed to promote economic growth, inhibits its growth instead. Excessive financial growth will lead to serious economic 
and social consequences. Scholars such as Lvina (2012) and Lapavitsas (2013) proposed the theory of financial grabbing. They pointed out that financial profits were essentially surplus value and profit on alienation. The former came from the exploitation of workers' surplus labor by industrial capitalists in the field of production, and the latter resulted from the "financial grabbing" to the monetary income holder class by financial capitalists using the financial system in the field of circulation. Foroohar (2016) vividly likened the financial sector to the "taker" of value. The depth and breadth of the relationship between the rise of finance and the increased inequality, failure of new businesses, stagnant wages and political dysfunction clearly indicated that finance not only exceeded the real economy but also substantially inhibited the growth of the latter. Countries with a large-scale and fast-growing financial system tend to present "weaker" productivity growth. The development of the financial sector and its high profits may attract talents, and the relative loss of talents in the real economy sector, especially in technology businesses, leads to a decline in the output efficiency and even the level of welfare of the whole society (Cecchetti and Kharroubi, 2015). Smith et al. (2003) analyzed the business performance of 13 European banks and found that GDP growth was negatively related to bank profitability. In domestic studies, Xing et al. (2013) performed principal component analysis (PCA) on the data of 14 commercial banks in China from 2004 to 2011. The empirical results indicated that the correlation coefficient between the real GDP growth rate and the ROA of commercial banks was negative. Zhang and $\mathrm{Wu}$ (2013) conducted an empirical analysis using a large sample of microeconomic enterprise data and found that the cost of loans had significant "squeezing" and "inhibiting" effects on corporate profits and asset growth in private enterprises but a "symbiosis" effect in state-owned enterprises, and none of these effects were found in other types of enterprises. Wen et al. (2020) established an industry-finance profit-sharing index and found that there was a significant negative relationship between the index and the economic growth rate after testing by dynamic panel generalized method of moment (GMM), concluding that there was financial excess at the level of industry and finance profit sharing. These studies verified that the banking system had an "interest grabbing" effect on the real economy. Based on the above analysis, we proposed Hypothesis 2:

H2. The development of the banking industry has a negative effect on the growth of the real economy; that is, the more profitable the banking industry, the slower the growth of the real economy.

(3) The view of asymmetric financial symbiosis. The financial function view argued for the positive effect of the financial sector on the real economy regarding resource allocation, while the view of finance grabbing profits demonstrated the negative effect of the financial sector on the real economy from the perspective of profit distribution. However, due to historical limitations, the above studies were carried out under the framework of a linear model based on ideal assumptions. Thus, their conclusions were naturally either negative or positive. After the financial crisis in 2008, more and more foreign scholars believed that financial development and economic growth had an asymmetric symbiosis relationship instead of a single linear one (Huang et al., 2009; Law and Singh, 2014). From the "sharing" concept of China's new development philosophy, the outbreak of the global financial crisis has inspired Chinese scholars to review the relationship between financial development and economic growth from a nonlinear perspective (Du, 2008; Huang and Dong, 2013; Wang and Pan, 2018). Li and Chang (2014) tested the relationship between the profits 
CPE

4,2

150

of 106 Chinese banks and the real economy from 2001 to 2011, using a nonlinear panel smooth transition regression (PSTR) model. The results of their study indicated that the whole real economy and the secondary and tertiary industries had a nonlinear positive influence on the structural changes of bank profits. Fan et al. (2021) tested the "live and let live" relationship between economy and finance using the panel data of provinces and regions in China from 1993 to 2017. The results suggested that China's economy and finance did have a "live and let live" relationship, which, however, remained at a state of positive asymmetric symbiosis. The promotion of finance to the real economy was less than the contribution of the real economy to finance. Hence, we proposed Hypothesis 3:

H3. The development of the banking industry has a nonlinear influence on the growth of the real economy. The banking industry's profitability within different threshold ranges has different levels or directions of impact on the growth of the real economy.

In summary: (1) The relationship between finance and the real economy has always been a controversial topic in the theoretical circle, and the issue of the financial sector's high profits has attracted social attention repeatedly. Despite the massive facts and data regarding the high profits of the financial sector given by domestic and foreign scholars, existing studies have yet to give a convincing explanation and reasonable solution. (2) The ultimate source of the financial sector's profits is the real economy - this correct conclusion by Marx has always been the logical starting point of scholars in previous research on such issues. No evidence of the theory of monetary neutrality in classical economics can be found in the short-term economic development history. According to traditional financial development theories, financial development can promote economic growth. However, studies of other schools have indicated that excessive financial development will harm economic growth. (3) After the financial crisis in 2008, with the expansion of research perspectives and the progress of econometrics research methods, studies of the relationship between finance and the real economy based on the nonlinear theoretical framework became mainstream. The conclusion of research on the asymmetric symbiosis between economy and finance reflects the reality better.

Based on the systematic summary of the existing research results, we analyzed the asymmetric relationship between finance and economy through typical fact analysis and empirical testing based on the panel threshold model, accurately portrayed the profit threshold of the banking industry and explored the empirical value for the symbiotic development of the banking industry and the real economy. Section 1 is the introduction of the background and research significance; Section 2 is a review of domestic and foreign literature; Section 3 presents the theoretical mechanism and factual analysis; Section 4 is empirical analysis; Section 5 is about research conclusions and policy recommendations.

\section{Theoretical mechanism and factual analysis}

\subsection{Theoretical mechanism of profit sources in the financial sector}

First, the real economy is the only source of the profit of financial capital. Based on criticism and absorption of research results of the classical school, Karl Marx divided financial and industrial capital and explored the source and nature of profits in the financial sector. In Volume III of Capital (2004), he mentioned that "interest, as we have seen in the two preceding chapters, appears originally, is originally, and remains in fact merely a portion of the profit, i.e., of the surplus-value" (Marx, 2004, p. 415). Essentially, financial profit is a division of industrial profit. Scholars represented by Foley (2013) and Mavroudeas (2018) insisted on Marx's labor theory of value that surplus value was the only source of financial profit and that increase in financial profits achieved by financial capitalists through "manipulation of expectations and contingent contracts" could not bring about an increase in the global total 
surplus value. According to Capital in the Twenty-First Century (Le Capital au xxie siecle) authored by French economist Piketty (2014), the rate of return on financial assets greatly exceeds that of traditional methods, and financial capital is able to dynamically and selectively participate in the distribution of profits in industries with better rates of return and is thereby able to maintain higher levels of profitability.

Second, high financial profits are derived from market monopolies and the interest margin under regulation. According to Marx's theory of profit equalization, the premise of profit equalization is the free movement of capital and labor. Compared to the real economy, which is competitive, the financial sector is characterized by high risk and strict supervision, and even if monopolistic regulations are revoked, there is still an "entry threshold" in this sector. The "Big Four" (four largest) banks in China occupied a market share of 35.6\% in asset scale at the end of 2019, and the monopolistic competitive environment protected by policy barriers enabled large banks to gain a systemic market power premium steadily. Increasingly, strict controls on banks' cross-regional operations led to administrative barriers to the movement of credit resources between regions (Lin et al., 2020). The "high threshold and strict access" will, to some extent, prevent the financial sector's profits from converging toward the average. Especially in a financial environment with the tightening of market funds, financial institutions can set various financing conditions for businesses to ensure that they can gain high profits without being affected by business conditions. Under the inflation conditions, the lending rate is timely adjusted with the increase in the rate of return on investment (ROI), while the deposit rate has a sticky response to inflation. Therefore, the banks' interest margin widens, which is the cause of high banking profits (Wu et al., 2018).

Third, high financial profits stem from the faith in rigid payment and the lack of exit mechanisms. In most developing countries, due to causes such as policy protection, performance appraisal management and imperfect market mechanisms, the financial sector tends to seek short-term profits in operation. Banks compete with each other, relying blindly on scale expansion and consistent pricing rather than differentiation. For the purpose of industry protection and social stability, rigid payment is relatively common in the financial sector, and the "illusion" of large scale and high profits of the banking industry is maintained by "relay game" and "Ponzi finance" rules and asset bubbles in the financial market and lending market. In reality, some "zombie" companies delay risk exposure through loan repayment with loan, loan extension, government coordination, etc. Some banks cover up material risks through false disposal, leading to continuous accumulation of business risks. Once hit by external emergencies, the profit model of financial capital will be hard to sustain and followed by takeover, restructuring, bankruptcy and closedown of businesses. Financial risks are unable to be cleared due to the lack of an exit mechanism, which becomes a crucial cause of banks' high book profits.

Fourth, the excessive inflation of the financial sector increases the debt risk of the real industry. With investments in real estate, urban infrastructure and other capital-intensive industries, the financial sector can rapidly expand the scale of assets, forming a deep intertwining of finance with real estate and fiscal sector and bubbling risks. Many businesses make their capital flow from the industrial platform to high-risk, nonreal economic fields, such as finance and real estate, to gain short-term profits faster and more reliably, resulting in the "financialization" of the economy and "irrational prosperity" with hollowed-out industries and high leverage. Scholars, including Piketty (2014), pointed out that the financial system created the drive itself to ensure that this distorted relationship between finance and the real economy could last for a long time. The high profits of the financial sector have rapidly widened the wealth gap between financial practitioners, financial speculators and the general public, causing a sharp increase in social inequality and further undermining the economic growth potential through the consumption mechanism. Bakija et al. (2012) found that before the financial crisis began, the proportion of financial professionals in the top $1 \%$ of income
Threshold of symbiosis 
CPE

4,2

152

earners in the USA almost doubled from 1979 to 2005. Marx also said that cyclical financial crises were triggered by the exponential growth of debts regardless of actual productivity growth. The interest levied on increasing debts takes income away from industry, commerce and individuals, leaving less disposable income to be spent on goods and services and a shrinking economy.

Fifth, the rupture of financial bubbles causes a long-term drag on the growth of the real economy. The financial sector takes a share of the profits created by the real economy, relying on risk-taking during economic upswings and achieves capital accumulation. When the economy is down and risks occur in succession, the profits previously gained by financial institutions are inevitably taken back, causing erosion to capital and bankruptcy of financial institutions, which may trigger an economic crisis in serious cases. Thus, the cyclical interaction and feedback of economy and finance regarding the distribution of profits are formed. Regardless of differences in the financial development level, when the financial system is trapped in the high-risk exposure period, blindly requiring financial institutions to reduce financing interest rates universally and continuously, while ignoring the "self-restoration" of finance itself, may cause problems in two aspects: First, profits fail to cover risks. The decline in profits weakens the replenishment of internal capital sources and indirectly affects that of external sources, leading to a gap in the replenishment of financial capital and the ultimate loss of capacity to nurture the real economy. In the 1990s, China's financial system dominated by state-owned banks was closely coupled with administrative regulation. Most of the financial resources were occupied by state-owned enterprises. The banking industry essentially had no positive net interest margin (NIM) and became the "second fiscal sector" with low efficiency and rising risks, deep in debt for up to a decade. Second, banks are reluctant to lend money. Loan interest rates go down nominally, but it makes it difficult to borrow money, which is detrimental to the real economy. The distribution of profits between the financial sector and the real economy must maintain a reasonable balance. Liu (2013) mentioned in the Comparative Study of Two Great Global Crises that there were three banking crises in the USA during 1930-1933, which exacerbated the economic recession. In particular, the second banking crisis in the USA in 1931, caused by the negative spillover shocks from the problems of the European financial system, was a deep drag on the real economy and was considered the real beginning of the "Great Depression”.

\subsection{Interactive characteristics of China's banking profits and the growth of the real economy}

According to the definition of the real economy by Huang (2017), the national economy is defined as the real economy after the exclusion of the financial and real estate sectors. We compared the GDP growth rate of the real economy with the net profit growth of the banking industry, and the result is shown in Figure 1. Since the financial crisis in 2008, the growth of profits of China's banking industry has generally presented consistent fluctuation with the growth of the real economy. With 2015 as the cut-off point, the relationship can be divided into two different stages:

Stage I, financial crisis-2014: During this period, the banking industry's net profit growth rate was continuously higher than the real economy's growth rate, both with sharp fluctuation. During the financial crisis, the growth rate of the real economy was impacted and reduced, and the net profit growth rate of the banking industry also dropped from $48.1 \%$ in 2007 before the crisis to $14.6 \%$ in 2009 after the crisis. After the occurrence of the financial crisis, to hedge against its negative impact, China began to implement a large-scale monetary stimulus policy in 2009. The balance of banking assets increased from RMB63 trillion at the end of 2008 to RMB113 trillion at the end of 2011, and the scale of assets almost doubled in three years. Meanwhile, financial asset prices were also rising, with a rapid increase in loan 


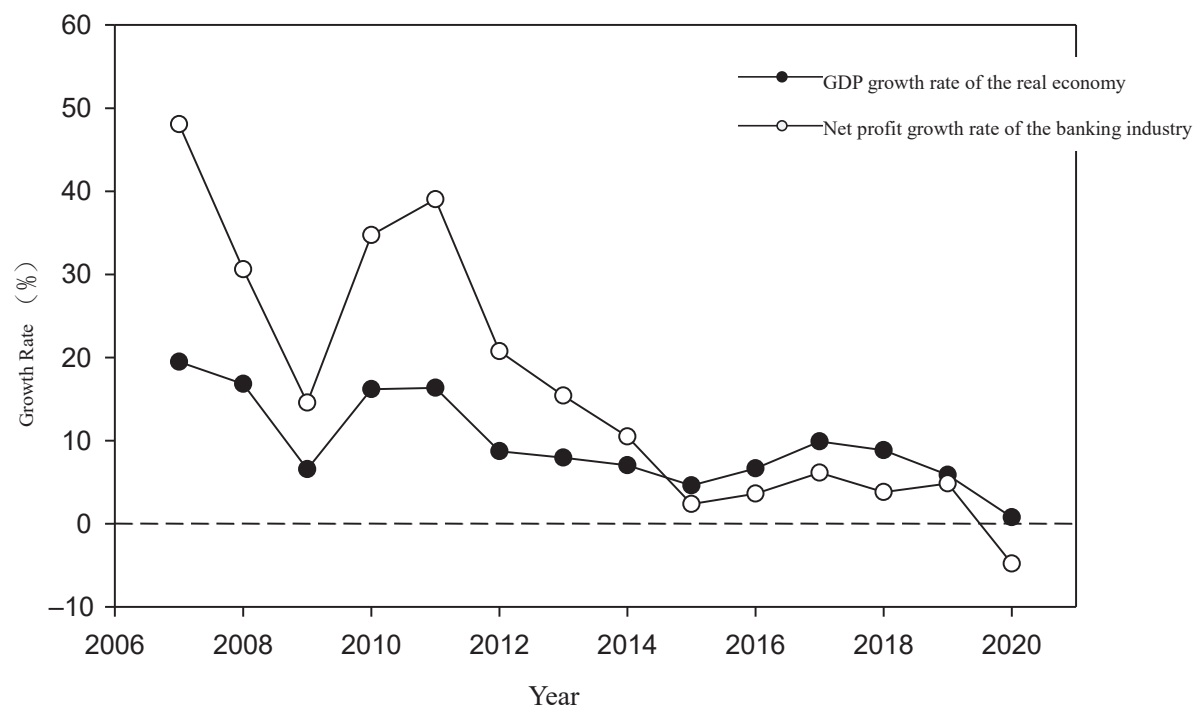

Threshold of symbiosis

153

interest rates. The NIM of the banking industry climbed from $2.42 \%$ in 2009 to $2.82 \%$ at the end of 2011, an increase of $0.4 \%$ in three years. The "bump in both price and volume" drove the rapid growth of banking profits. The net profit growth rates of the banking industry in 2010 and 2011 were 34.73 and $39.03 \%$, respectively, far higher than the GDP growth rate of the real economy. Subsequently, with the tightening of monetary policy, the asset expansion of the banking industry slowed down. However, with the support of a stable interest margin (NIM stabilized at around 2.8\%), although the real economy entered $L$-shaped growth stage, the banking industry still maintained a relatively high level of profit growth, and its high profitability trend continued until 2014.

Stage II, 2015-2020: During this period, the net profit growth rate of the banking industry continued to be lower than the growth rate of the real economy, and their trends were relatively stable. In 2015, China formally launched the supply-side structural reform. The "three removals, one reduction and one improvement" policy (cutting excess capacity, destocking, deleveraging, reducing corporate costs and improving weaknesses) promoted the accelerated transformation and upgrading of the real economy. The financial management department enhanced financial governance, standardized and rectified the "idle circulation" chaos in the financial system. The net profit growth of the banking industry roughly matched the growth of the real economy. During this period, key progress was made in the reform of interest rate marketization. On October 24, 2015, the central bank no longer set ceilings on deposit rates for commercial banks and rural cooperative financial institutions, marking China's basic relaxation of interest rate controls. The loan prime rate (LPR) reform initiated in 2019 guided commercial banks to lower loan pricing. Currently, the one-year LPR is $3.85 \%$, and the LPR for five years or more is $4.65 \%$, down 0.4 and $0.2 \%$ from those before the reform, respectively. The trend of interest rates for deposits/loans and deposit-loan spreads in China's banking industry (Figure 2) indicates that the average interest rate of loans in the banking industry is close to the historical low during the financial crisis in 2009. The NIM of the banking industry fell to $2.62 \%$ in $2015,2.09 \%$ in 2016 and has remained at about $2 \%$ ever since. Meanwhile, the growth of asset scale in the banking industry also fell to single digits from double digits. The "fall in both price and volume" caused a sharp decline in the net profit growth rate of the banking industry. Due to the substantial fee cuts and interest concessions 


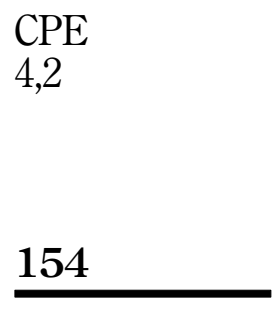

Figure 2.

Trends of interest rates for deposits/loans and deposit-loan interest margin in China's banking industry

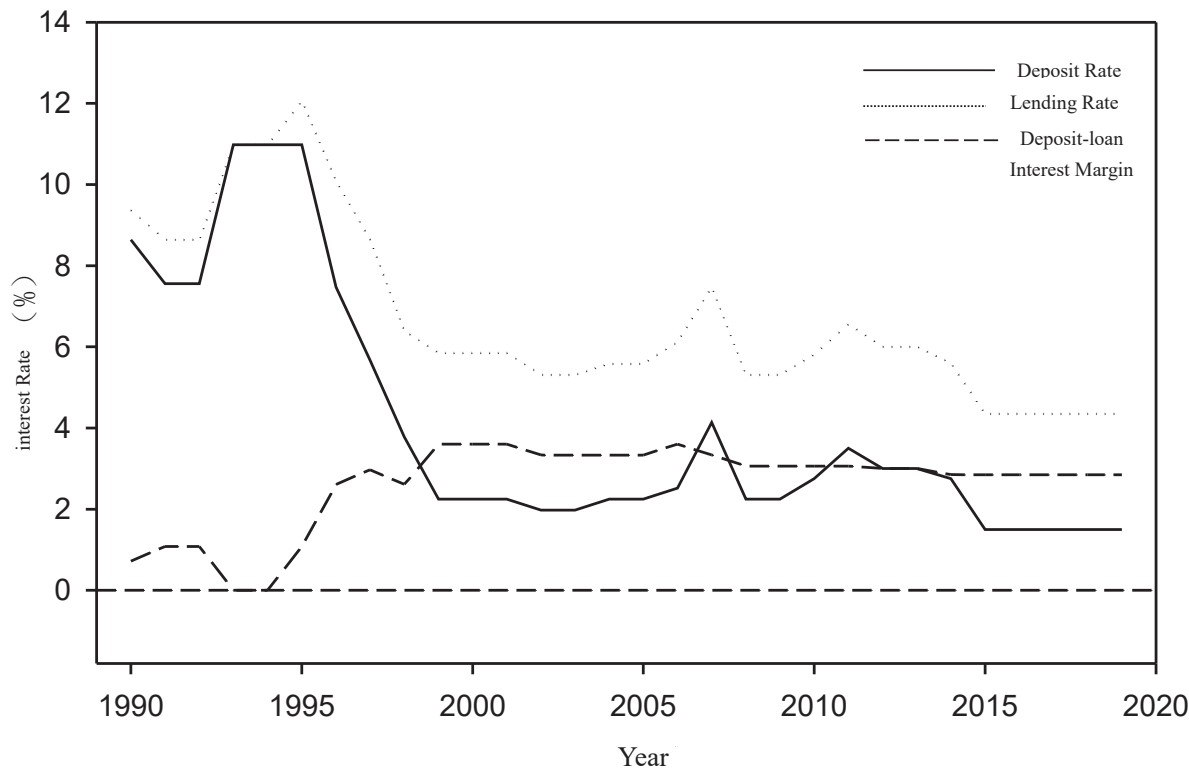

during the pandemic in 2020, the net profit of the banking industry even showed negative growth. Meanwhile, in the context of deleveraging and strict regulation, the channels for inflated profit in the banking industry were blocked, and some small and medium-sized banks "could not make ends meet" and faced capital shortfalls.

\subsection{Comparative analysis of the profitability of the banking industry in China, USA, Japan and Germany}

To determine the level of profitability of China's banking industry more objectively and comprehensively, we need to look beyond China and conduct a comparative analysis between China and other countries from a global perspective. We selected the USA and Japan with similar economic volumes and Germany, the real economy model, for comparative analysis.

First, we made Figure 3 using the added value of the financial sector as an analysis indicator. Since the global financial crisis in 2008, the proportion of the added value of the financial sector in the GDP of China and the USA were basically consistent and continued to rise, approaching $8 \%$ in 2019. Different from China and the USA, the proportion of the added value of the financial sector in the GDP of Japan and Germany was consistent, which maintained a continued downward trend and was close to $4 \%$ in 2019 , widening the gap with China and the USA. This might be related to the fact that Japan and Germany attached more importance to the development of the real economy and remained prudent to the growth of the financial sector in general, which could be corroborated by the great manufacturing strength of Japan and Germany.

Second, we compared the proportions of profits of the financial sector and the banking industry in major securities exchange markets in China, USA, Japan and Germany (i.e., Shanghai Stock Exchange, Shenzhen Stock Exchange, New York Stock Exchange, Tokyo Stock Exchange, Frankfurt Stock Exchange), using the net profit as an analysis indicator. The results are shown in Table 1 . The analysis results indicate that among A-share listed companies in China during 2016-2019, the net profit of companies in the financial sector accounted for more than $50 \%$ of the total profits of listed companies and the net profit of the 


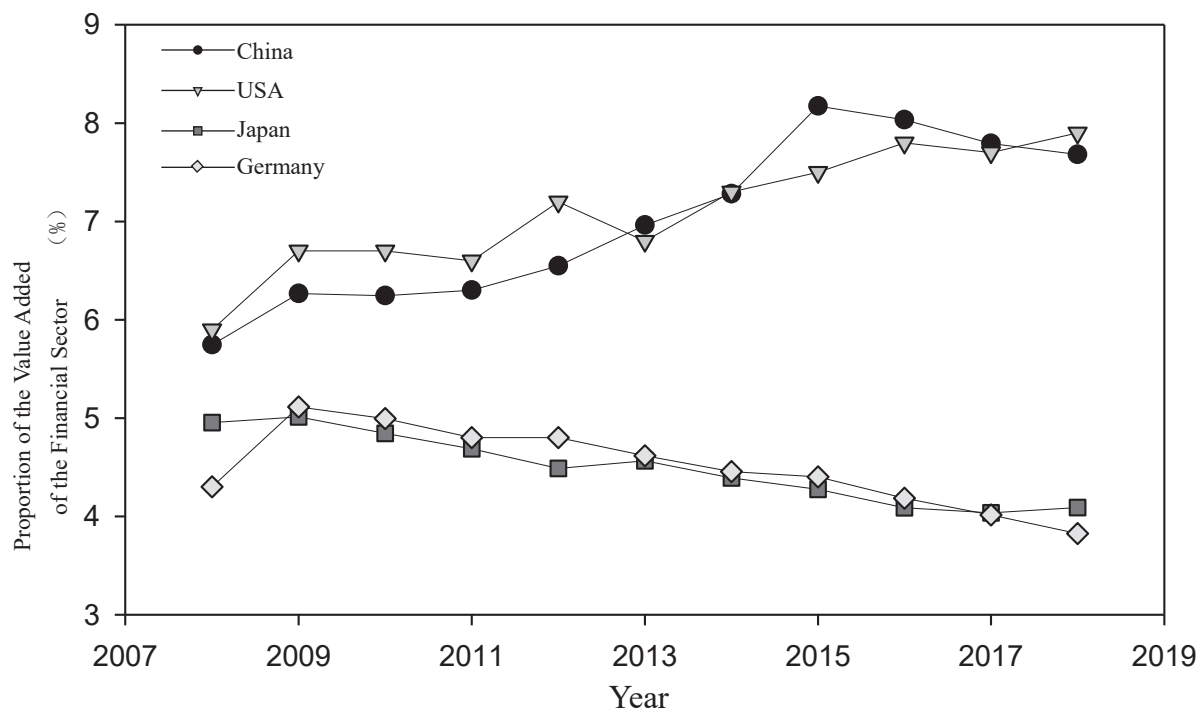

Threshold of symbiosis

155

Figure 3.

Trends in the proportion of the added value of the financial sector in GDP of China, USA, Japan and Germany

\begin{tabular}{|c|c|c|c|c|c|c|}
\hline Region & Year & $2016(\%)$ & $2017(\%)$ & $2018(\%)$ & $2019(\%)$ & \\
\hline \multirow[t]{3}{*}{ China } & Financial sector & 52.71 & 47.05 & 47.58 & 51.27 & \\
\hline & Including: banking & 43.95 & 38.42 & 40.36 & 40.45 & \\
\hline & Real economy & 42.47 & 47.74 & 45.95 & 42.08 & \\
\hline \multirow[t]{3}{*}{ USA } & Financial sector & 21.21 & 22.66 & 22.12 & 26.17 & \\
\hline & Including: banking & 20.04 & 21.80 & 21.36 & 25.08 & \\
\hline & Real economy & 78.74 & 77.31 & 77.81 & 73.82 & \\
\hline \multirow[t]{3}{*}{ Japan } & Financial sector & 15.68 & 15.39 & 14.19 & 14.55 & \\
\hline & Including: banking & 8.31 & 7.98 & 7.05 & 7.03 & \\
\hline & Real economy & 81.42 & 82.05 & 84.00 & 81.79 & Comparicon of the net \\
\hline \multirow{3}{*}{ Germany } & Financial sector & 4.35 & 11.67 & 14.86 & 14.65 & Comparison of the net \\
\hline & Including: banking & -4.29 & 5.79 & 7.99 & 8.15 & companies on the stock \\
\hline & Real economy & 91.57 & 85.76 & 82.30 & 82.75 & exchanges in four \\
\hline \multicolumn{6}{|c|}{ Note(s): Data source: Wind } & countries \\
\hline
\end{tabular}

banking industry accounted for over $90 \%$ of that in the financial sector, while the net profit of the real economy accounted for less than $50 \%$ of the total net profits. In terms of the trend, after 2017, the net profit of China's real economy accounted for a higher proportion in the total than that of the banking industry, which was closely related to the reduction in the net profit growth rate of the banking industry to lower than the GDP growth rate of the real economy after 2015 as analyzed above. This suggests that the Chinese government has made a phased achievement in the governance of the financial sector after the National Financial Work Conference to some extent.

Among companies listed on the New York Stock Exchange (NYSE) in the USA, the net profit of the banking industry accounted for $20-30 \%$ of the total net profits, and the net profit of the real economy always accounted for more than $70 \%$. Among companies listed on the Tokyo Stock Exchange (TSE) in Japan, the net profit of the banking industry accounted for less than $10 \%$ of the total net profits, while that of the real economy accounted for more than 
CPE

4,2

156

$80 \%$. Germany has always maintained prudential supervision over the financial sector. The proportion of the net profit of the German banking industry in the total net profits was similar to that in Japan, and the net profit of the German real economy sector accounted for more than $90 \%$. From this perspective, the proportion of the net profit of the banking industry in China's capital market was generally higher than that in the capital markets of major developed economies such as the USA, Japan and Germany. As the banking industry, which is a financial intermediary, does not create value, the high profit of the banking industry indicates the high cost of financing in the real economy. The high banking profits are essentially about taking a share of capital returns of the real economy, which will inevitably weaken the competitive advantage of the real economy. In contrast, the proportion of the net profit of the real economy always remained dominant in Japan's and Germany's capital market, which was one of the crucial reasons why Japan's and Germany's industrial economies were worldrenowned and their real industries continued to flourish.

Third, we conducted a comparative analysis using the relative quantitative indicator of ROE to measure the profitability of China's banking industry. The results are shown in Table 2. Since the "13th Five-Year Plan", the overall ROE of China's banking industry has remained above $10 \%$ among the listed companies on the Chinese capital market, whereas the ROE of China's real economy sector has been below $10 \%$, lower than that of the banking industry. Financial capital profit constitutes the production cost of the real economy. The ROE of the financial sector higher than the social average profit rate for a long period of time may lead to overhigh financing costs and the erosion of the profit rate in the real economy. Thankfully, in the past five years, the ROE of China's banking industry has shown a gradual downward trend and that of the real economy has generally remained stable.

Regarding the USA, Japan and Germany, the overall ROE of the banking industry among the companies listed on the NYSE in the USA was less than 10\%, while that in Japan and Germany was as low as around 5\%. The ROE of the real economy in the USA, Japan and Germany was generally higher than that of the banking industry of these countries, which was in sharp contrast to the trend in the Chinese capital market where the ROE of the banking industry continued to be higher than that of the real economy. The development practice of financial markets in the USA, Japan and Germany has verified that it is not necessarily bad to have a relatively low-profitability of the financial sector, which prevents the financial sector from gathering excessive social resources and overheating. The economy plays the role of "blood supply" to the "body" of the economy. In the long run, maintaining a low-profit rate in the financial sector is conducive to reducing the financial cost of the real economy and

\begin{tabular}{llrrrr}
\hline Region & Year & $2016(\%)$ & $2017(\%)$ & $2018(\%)$ & $2019(\%)$ \\
\hline \multirow{2}{*}{ China } & Financial sector & 13.87 & 13.27 & 12.39 & 12.29 \\
& Including: banking & 14.16 & 13.30 & 12.59 & 11.90 \\
& Real economy & 7.65 & 9.34 & 8.06 & 7.34 \\
\multirow{2}{*}{ USA } & Financial sector & 8.16 & 9.38 & 7.60 & 7.22 \\
& Including: banking & 8.15 & 9.38 & 7.76 & 7.30 \\
& Real economy & 12.52 & 14.58 & 11.44 & 10.47 \\
\multirow{4}{*}{ Japan } & Financial sector & 3.86 & 10.04 & 7.54 & 3.78 \\
& Including: banking & 4.21 & 6.54 & 4.28 & 2.92 \\
& Real economy & 15.86 & 15.18 & 10.26 & 5.65 \\
\multirow{4}{*}{ Germany } & Financial sector & 1.64 & 6.77 & 7.82 & 7.82 \\
& Including: banking & -2.60 & 4.55 & 5.75 & 4.99 \\
\multirow{2}{*}{ Note(s): Data source: Wind } & 7.78 & 20.07 & 12.53 & 11.04 \\
& Real economy & & & & \\
\end{tabular}

\section{Table 2.}

Comparison of ROE (weighted) of companies listed on the stock exchanges in four countries

Note(s): Data source: Wind 
facilitating the real economy's growth; the growth of the real economy, in turn, promotes financial development, thereby forming a virtuous circle.

Given that the NYSE in the USA, TSE in Japan and the Frankfurt Stock Exchange (FWB) in Germany are international financial markets, where listed companies cover high-quality companies worldwide, we excluded foreign companies in the stock markets based on the place of registration and again conducted a comparative analysis of local listed real-economy companies and banks' ROE (arithmetic average) in China, the USA, Japan and Germany, with the results shown in Figure 4.

The comparative analysis suggests that compared with developed economies such as the USA, Japan and Germany, the profitability of China's banking industry was at a relatively high level and continued to be higher than the net profitability of real-economy companies. Although it has presented a downward trend in recent years, the gap between the profitability of China's banking sector and that of China's real economy was widening rather than narrowing.

Finally, we selected global systemically important banks (G-SIBs) in China and the USA for comparison, focusing on microeconomic individuals. The results are shown in Table 3. It can be seen that the ROE levels of all Big Four state-owned banks in China (i.e., Industrial and Commercial Bank of China, Agricultural Bank of China, Bank of China, China Construction Bank) have been above $10 \%$. After the financial crisis, the profitability of five major banks in the USA has gradually recovered, close to that of large banks in China. However, in terms of the scale, all Big Four banks have an asset scale of more than RMB20 trillion presently, which is 8-10 times that of the top five banks in the USA. In this regard, the banks in China have the issue of diseconomies of scale. With the long-term stability of interest margin, the continuous expansion of China's banking industry has become the main drive for high-profit growth. The huge amount of loans granted has expanded the scale of banks' interest-bearing assets, magnified the advantage of interest margin and supported the high profits of banks. For example, at the end of 2020, the total assets of China's banking industry reached RMB319 trillion, six times that in 2007 before the financial crisis, with an average compound annual growth rate (CAGR) of $15 \%$, exceeding the growth rate of net profit by $1.4 \%$.

\section{Empirical analysis}

Literature review and theoretical mechanism analysis suggest that the profit of the banking industry stems from the value created in the real economy, and the banking industry will affect the growth of the real economy indirectly by sharing the profit of the real industry. The analysis of the development facts on the profitability of the banking industry and the growth of the real economy indicates that the profit level of China's banking industry is generally higher than that of the real economy and also higher than that of major developed countries. Whether the profit level of China's banking industry inhibits, promotes or has a symbiotic relationship with the growth of the real economy needs to be further demonstrated scientifically. Next, the hypotheses proposed in the previous sections are tested empirically using quantitative analysis methods to characterize the threshold relationship between them.

\subsection{Variable selection and model design}

Essentially, the paper studies the relationship between finance and the economy. The international literature on the relationship between finance and economic growth has developed a set of scientific methods for variable selection. In the research literature on finance and economic growth, per capita GDP is the most common variable used to represent economic growth, while the added value and profit indicators of the financial sector are used as financial proxy variables. In this paper, the logarithmic value of per capita real economy 
CPE

4,2

158
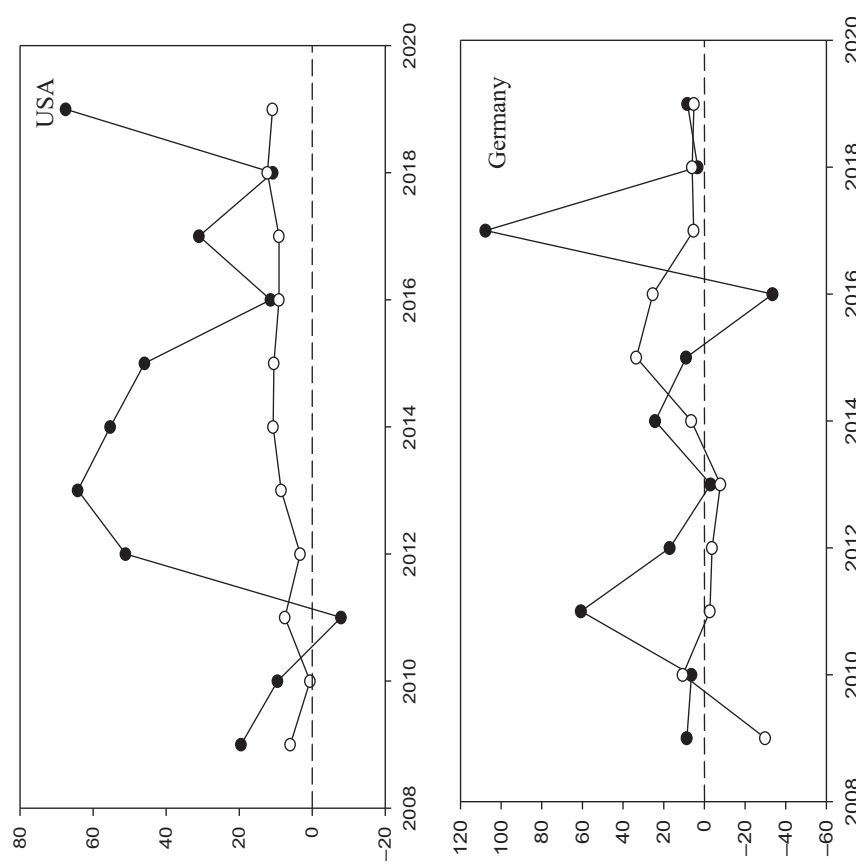

ํํํ

$\stackrel{\infty}{\frac{\infty}{2}}$

$\stackrel{\infty}{\stackrel{N}{2}}$

$\stackrel{\text { S }}{\frac{N}{2}}$

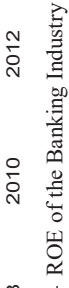

$\stackrel{\infty}{\circ}$

옹 䒕

ก

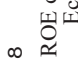

$\stackrel{\infty}{\circ}$

iे

$\stackrel{\infty}{\stackrel{\infty}{2}}$

离

$\stackrel{\text { ก }}{\stackrel{N}{ }}$

Figure 4.

Comparison of ROE between local listed real-economy

companies and banks in four countries 


\begin{tabular}{|c|c|c|c|c|c|c|c|}
\hline \multicolumn{2}{|c|}{ ROE of $G$-SIBs ( $\%)$} & \multirow{2}{*}{$\frac{2016}{9.86}$} & \multirow{2}{*}{$\frac{2017}{9.59}$} & \multirow{2}{*}{$\begin{array}{l}2018 \\
12.68\end{array}$} & \multirow{2}{*}{$\frac{2019}{14.07}$} & $\begin{array}{l}\text { Assets at the end of September } \\
2020 \text { (RMB100 m) }\end{array}$ & \multirow[t]{2}{*}{$\begin{array}{l}\text { Threshold of } \\
\text { symbiosis }\end{array}$} \\
\hline USA & J.P. Morgan & & & & & 32,461 & \\
\hline & Bank of America & 6.85 & 6.83 & 10.57 & 10.35 & 27,385 & \\
\hline & Citigroup & 6.67 & -3.19 & 9.09 & 9.96 & 22,345 & \\
\hline & Wells Fargo & 11.18 & 10.91 & 11.11 & 10.20 & 19,222 & \\
\hline & Goldman Sachs Group & 8.52 & 5.07 & 12.13 & 9.38 & 11,321 & 159 \\
\hline \multirow[t]{4}{*}{ China } & $\begin{array}{l}\text { Industrial and Commercial } \\
\text { Bank of China }\end{array}$ & 14.80 & 13.96 & 13.36 & 12.47 & 334,719 & \\
\hline & Agricultural Bank of China & 14.55 & 14.06 & 13.10 & 11.72 & 272,968 & \\
\hline & Bank of China & 12.12 & 11.86 & 11.58 & 10.82 & 247,039 & ROE and asset scale of \\
\hline & China Construction Bank & 15.38 & 14.44 & 13.56 & 12.72 & 282,981 & $G$-SIBs in China and \\
\hline \multicolumn{7}{|c|}{ Note(s): Data source: Wind } & the USA \\
\hline
\end{tabular}

GDP (excluding real estate and financial sectors) of provinces and cities in China was selected as the dependent variable, and the GDP deflator index was used to eliminate the impact of price factors. The data were collected from the Wind database. This paper aims to explore the threshold relationship between the net profit of the banking industry and the growth of the real economy. In terms of mechanism, the growth of the net profit of the banking industry affects the growth of the real economy by changing the profit-sharing structure of the real industry and the financial sector theoretically. Hence, referring to the method of variable selection by Wen et al. (2020), we established the industry-finance profit distribution index as an intermediate variable indicating the relationship between banking profit and the growth of real economy and measured by the ratio of banking net profit to industrial added-value. As the net profit value of the banking industry in various provinces and cities lacked direct data, we obtained the relevant data from the China Financial Statistics Yearbook, Regional Financial Operation Report by the PBC, the official websites of the China Banking Regulatory Commission (CBRC), $\mathrm{PBC}$ and the Banking and Insurance Regulatory Bureaus in various regions. In reference to previous studies, we also selected the following control variables: government fiscal expenditure, scientific research investment, industrial structure, fixed asset investment and financial deepening level. The range of data selected was from 2008 to 2019 in 31 provinces and cities, and some missing data were supplemented by linear interpolation. Unlike previous studies, this paper was not limited in merely discussing the positive or negative relationship between the growth of the real economy and the profit sharing of the banking industry. Instead, based on the consideration of the nonlinear relationship between variables, it took the net profit rate of the banking industry as a threshold variable and accurately measured the threshold of the banking industry's participation in industrial profit sharing based on the panel threshold model.

We used a fixed-effect panel data multithreshold model in this paper based on the panel data threshold models used by Zhao et al. (2007), Huang and Dong (2013), Wang and Pan (2018) to study the nonlinear relationship between finance and economy.

The model is set as follows:

$$
\begin{aligned}
P_{R G D P_{i t}} & =\sum_{a k} X_{i t}+\beta_{1} D R N F_{i t} I\left(N P R_{i t} \leq \gamma_{1}\right)+\beta_{2} D R N F_{i t} I\left(\gamma_{1}\right. \\
& \left.<N P R_{i t} \leq \gamma_{2}\right)+\beta_{3} D R N F_{i t} I\left(N P R_{i t}>\gamma_{2}\right)+u_{i}+\varepsilon_{i t}
\end{aligned}
$$

where the subscript $i$ indicates the province; $t$ indicates the year; $P R G D P_{i t}$ is the explained variable, which is represented by the logarithm of the per capita real economic value added; $D R N F_{i t}$ is the core explained variable, represented by the distribution rate of net profits for 
CPE

4,2

\section{0}

finance in industry $(D R N F) ; I(\cdot)$ is the indicative function, which is 1 when conditions in parentheses are established and 0 otherwise; $\gamma_{1}$ and $\gamma_{1}$ are the threshold to be estimated; $N P R_{i t}$ is the threshold variable, represented by the net profit rate of the banking industry; $X_{i t}$ is the selected control variable; $u_{i}$ is the individual fixed effect; $\varepsilon_{i t}$ is the error term; $\alpha$ is the coefficient of the control variable and $\beta$ is the coefficient of $D R N F_{i t}$.

Variable processing and data descriptive analysis are shown in Table 4.

\subsection{Empirical test and result interpretation}

When establishing the panel model, we first performed the threshold effect test to determine whether there was a threshold effect and how many threshold values were present. We used the bootstrap method provided by Hansen (2000) to test the statistic $p$-value and obtained the corresponding threshold. The number of self-sampling times was set to 300 . The sampling results are shown in Table 5.

The self-sampling results indicate that both Models 1 and 2 have passed the single threshold test, which suggests that there is a threshold effect in Models 1 and 2. Then, we tested the number of thresholds. Regardless of whether control variables are added, two thresholds are significant at the 5\% level, and the third threshold is not significant. Hence, both Models 1 and 2 can be established as dual-threshold models. The data are regressed based on the dual-threshold model, and the results are shown in Table 6.

\begin{tabular}{|c|c|c|c|c|c|c|}
\hline & Variable name & Mean & $\begin{array}{l}\text { Standard } \\
\text { deviation }\end{array}$ & Minimum & Maximum & Remarks \\
\hline $\begin{array}{l}\text { Explained } \\
\text { variable }\end{array}$ & $\begin{array}{l}\text { Logarithm of } \\
\text { per capita real } \\
\text { economy GDP } \\
\text { added value } \\
(P R G D P)\end{array}$ & 10.518 & 0.495 & 9.073 & 11.712 & $\begin{array}{l}\text { GDP net of industry } \\
\text { and finance, excluding } \\
\text { price }\end{array}$ \\
\hline $\begin{array}{l}\text { Core } \\
\text { explanatory } \\
\text { variable }\end{array}$ & $\begin{array}{l}\text { Distribution } \\
\text { rate of net } \\
\text { profits for } \\
\text { finance in } \\
\text { industry } \\
(D R N F)\end{array}$ & 0.094 & 0.136 & -0.517 & 1.145 & $\begin{array}{l}\text { Banking net profit/ } \\
\text { regional industrial } \\
\text { value added }\end{array}$ \\
\hline $\begin{array}{l}\text { Threshold } \\
\text { variable }\end{array}$ & $\begin{array}{l}\text { Net profit rate } \\
\text { of the banking } \\
\text { industry }(N P R)\end{array}$ & 1.039 & 0.437 & -2.287 & 2.074 & $\begin{array}{l}\text { (Banking industry's net } \\
\text { profit/banking } \\
\text { industry's total assets) } \\
* 100 \%\end{array}$ \\
\hline \multirow[t]{5}{*}{$\begin{array}{l}\text { Control } \\
\text { variables }\end{array}$} & $\begin{array}{l}\text { Fiscal } \\
\text { expenditure } \\
\text { rate }(F E R)\end{array}$ & 0.270 & 0.202 & 0.087 & 1.379 & \multirow{5}{*}{$\begin{array}{l}\text { Local fiscal } \\
\text { expenditure/regional } \\
\text { GDP } \\
\text { Logarithm of the } \\
\text { number of scientific } \\
\text { research personnel in } \\
\text { industrial enterprises } \\
\text { (Secondary } \\
\text { industry + tertiary } \\
\text { industry)/regional GDP } \\
\text { Fixed asset investment/ } \\
\text { regional GDP } \\
\text { Total deposits and } \\
\text { loans/regional GDP }\end{array}$} \\
\hline & $\begin{array}{l}\text { Enterprise } \\
\text { innovation } \\
\text { ability }(E I A)\end{array}$ & 10.289 & 1.687 & 3.091 & 13.377 & \\
\hline & $\begin{array}{l}\text { Industrial } \\
\text { structure (IS) }\end{array}$ & 0.898 & 0.053 & 0.710 & 0.997 & \\
\hline & $\begin{array}{l}\text { Investment rate } \\
\text { (IR) }\end{array}$ & 0.775 & 0.261 & 0.211 & 1.549 & \\
\hline & $\begin{array}{l}\text { Financial } \\
\text { deepening rate } \\
(F D R)\end{array}$ & 5.721 & 5.574 & 0.094 & 36.028 & \\
\hline
\end{tabular}

Table 4.

Statistical description of variables 
Table 6 indicates that there are three ranges for the changes in the net profit rate of the banking industry regardless of whether control variables are added or not. In these three different ranges, there are dynamic differences in the direction and intensity of the relationship between the distribution rate of net profits for finance in industry (DRNF) and the growth of the real economy. According to the analysis of Model 2 with the addition of control variables, there are two threshold values of the banking industry's net profit rate, which are 0.491 and $0.801 \%$. When the net profit rate of the banking industry is lower than $0.491 \%$, the distribution rate of net profits for finance in industry negatively affects the growth of the real economy, with an estimated coefficient of -0.812 . That is, within this profit range, increasing the banking industry's share of industrial profits is detrimental to the growth of the real economy. And for every $1 \%$ increase in the distribution rate of net profits for finance in industry, the growth rate of the real economy drops by $0.812 \%$, which suggests that at this point, the banking industry may be unable to provide financial support due to excessively low profitability that affects capital replenishment or may have a loan-reluctant sentiment in the case of being unable to maintain a stable operation, which will eventually drag down the real economy and cause financial repression. When the net profit rate is between 0.491 and $0.801 \%$, the influence of increasing the distribution rate of net profits for finance in industry on the growth of the real economy becomes positive, with an estimated coefficient of 1.334. That is, within this profit range, the profit distribution rate of industry and finance can promote the growth of the real economy. And for every $1 \%$ increase in the distribution rate of industry and finance, the growth rate of real economy will increase by $1.334 \%$, which suggests that within this range, the distribution of profits between the banking industry and the real economy is at the most balanced level and has achieved "live

\begin{tabular}{|c|c|c|c|c|}
\hline \multirow[b]{2}{*}{ Type } & \multicolumn{2}{|c|}{ Nationuide (no controluorioble) } & \multicolumn{2}{|c|}{$\begin{array}{c}\text { Model } 2 \\
\text { Nationwide (including control } \\
\text { variables) }\end{array}$} \\
\hline & Threshold & $F$-value & Threshold & $F$-value \\
\hline $\begin{array}{l}\text { Single threshold } \\
\text { Double threshold } \\
\text { Triple threshold }\end{array}$ & $\begin{array}{l}0.0177^{* *} \\
1.1864^{* * *} \\
-1.3853\end{array}$ & $\begin{array}{l}39.89 \\
36.14 \\
26.76\end{array}$ & $\begin{array}{l}0.4910^{* * *} \\
0.8012^{* *} \\
1.2073\end{array}$ & $\begin{array}{l}19.87 \\
13.19 \\
10.27\end{array}$ \\
\hline
\end{tabular}

Note(s): ${ }^{* * * * *}$, and ${ }^{*}$ indicate significance at the level of $1 \%, 5 \%$, and $10 \%$, respectively; the same as in the table below
Threshold of symbiosis

161

\begin{tabular}{|c|c|c|}
\hline Variable & $\begin{array}{l}\text { Model } 1 \\
\text { Nationwide (no control variable) }\end{array}$ & $\begin{array}{l}\text { Model } 2 \\
\text { Nationwide (including control variables) }\end{array}$ \\
\hline FER & & $0.830^{* * *}(0.261)$ \\
\hline$E I A$ & & $0.282^{* * * *}(0.0300)$ \\
\hline IS & & $4.345^{* * *}(0.623)$ \\
\hline$I R$ & & $0.425^{* * *}(0.0601)$ \\
\hline$F D R$ & & $0.0348^{* * *}(0.00301)$ \\
\hline$D R N F\left(N P R \leq \gamma_{1}\right)$ & $-2.794^{* * *}(0.525)$ & $-0.812^{* * *}(0.240)$ \\
\hline$D R N F\left(\gamma_{1}<\bar{N} P R \leq \gamma_{2}\right)$ & $2.903^{* * * *}(0.362)$ & $1.334^{* * * *}(0.340)$ \\
\hline$D R N F\left(N P R>\gamma_{2}\right)$ & $1.235^{* * *}(0.219)$ & $0.361^{* * * *}(0.111)$ \\
\hline Constant & $10.287^{* * *}(0.0324)$ & $2.921^{* * * *}(0.488)$ \\
\hline$F$ & 24.37 & 195.98 \\
\hline$R^{2}$ & 0.178 & 0.825 \\
\hline Number of samples & 372 & 372 \\
\hline
\end{tabular}

Table 6.

Regression results of threshold models
Threshold selfsampling results 
CPE

4,2

162

and let live". However, when the net profit rate of the banking industry exceeds $0.801 \%$, the increase of the distribution rate of net profits for finance in industry still positively affects the growth of the real economy, but the estimated coefficient is reduced to 0.361. This indicates that within this profitability range, the promotion effect of the banking industry's share of industrial profits on the growth of the real economy is greatly weakened, and for every $1 \%$ increase in the distribution rate of net profits for finance in industry, the growth rate of the real economy can increase by $0.361 \%$ only, which suggests that the banking industry dominates over the real economy sector in the distribution of profits, making the banking industry more profitable, squeezing the profit space of the real economy and greatly weakening the role of the banking industry in promoting the growth of the real economy.

The above table shows that at the current stage, there are generally three different dynamic relationships between the profitability of China's banking industry and the growth of the real economy, i.e., the negative relationship at low profit levels, the optimal positive relationship at medium profit levels and the low positive relationship at high profit levels, and no detrimental relationship to the real economy due to the high profitability level of the banking industry has been observed. This also fully verifies that the relationship between the growth of the net profit of the banking industry and the growth of the real economy in China generally conforms to the asymmetric symbiosis characteristics in Hypothesis 3 , instead of the linear characteristics in Hypotheses 1 and 2.

\subsection{Further analysis and verification of the profitability in the banking industry}

We analyzed the states of the net profit rates of the banking industry in different periods of development in China based on the thresholds obtained by empirical tests. As shown in the timing diagram Figure 5, in the decade since the financial crisis of 2008, the net profit rate of China's banking industry has generally been higher than the second threshold $(0.801 \%)$ and in a state of weak promotion to the growth of the real economy. During 2012-2015, while the business operations of real-economy enterprises were in difficulties and the economic growth rate began to decline, the net profit rate of the banking industry remained high and even increased to some extent. Until after 2020, with the Chinese government urging the financial sector to make massive fee cuts and interest concessions to the real economy, the net profit rate of the banking industry fell to $0.71 \%$, entering the optimal range of profitability status in relation to the real economy. This conclusion verified the above findings of factual analysis. Overall, the profitability of China's banking industry in the past decade or so has maintained a positive effect on the development of China's real economy, and there has been no negative damage to the real economy caused by excessive profitability. However, we have also found that the profitability of China's banking industry was relatively high compared to that in major economies worldwide, and the promotion efficiency of the banking industry to the real economy was not optimal, which was somewhat related to the different stages of economic and financial development. It is encouraging to note that in recent years, China has clarified the direction of financial reform and guided the banking industry through a series of reform initiatives to tighten the profitability level to the average profitability level of the industry, and the symbiotic relationship between the financial sector and the real economy has become clearer and more stable. However, it is necessary to keep a clear understanding of the bottom line of the banking industry's profitability and avoid unrealistic and irrational simple cuts of interest rates to prevent slipping into the low profitability range and resulting in a vicious circle of economic downturn and financial depression.

\subsection{Robustness test}

4.4.1 The measurement method and sample size were changed. In Model 1, the per capita real economic value added was replaced by the real economic value added, while in Model 2 , 


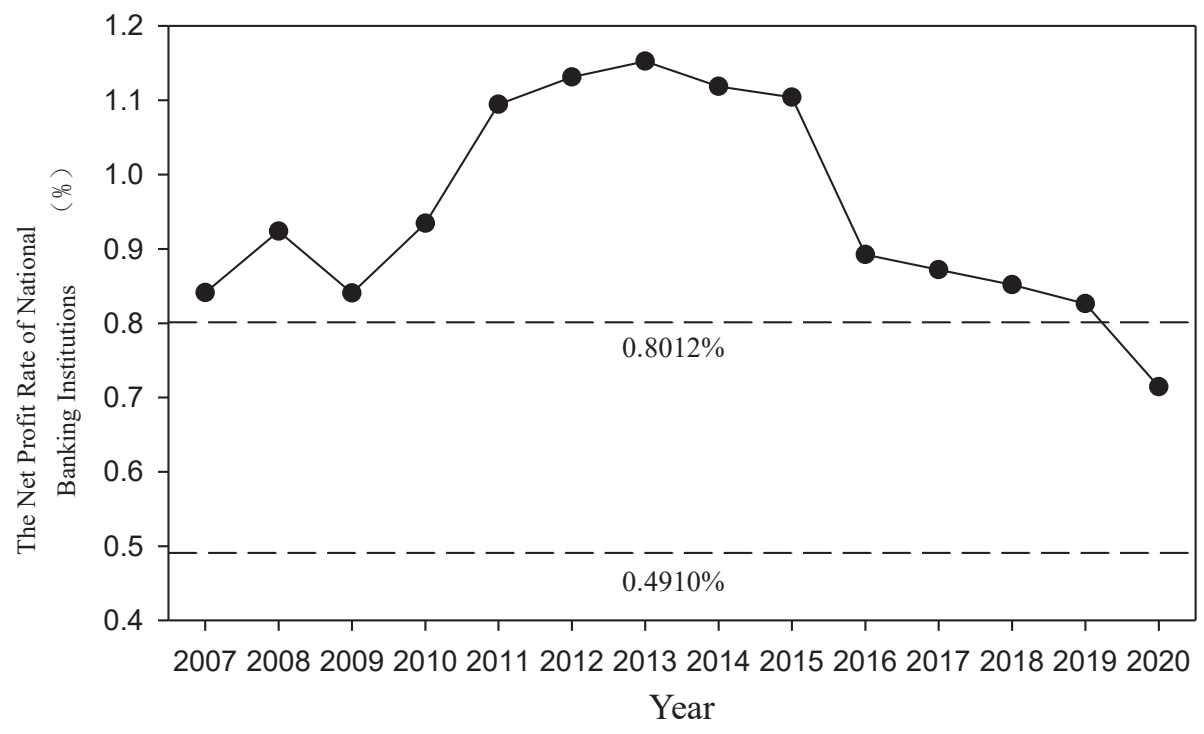

Threshold of symbiosis

163

Figure 5.

Trend diagram of the average net profit rate of the banking industry

samples from western China were removed, and those from eastern and central China were retained.

4.4.2 The estimation method was changed. The dual-threshold model test indicates that in different net profit ranges, the relationship between the development of the banking industry and the real economy presents a $U$-shaped asymmetric distribution feature; that is, a negative correlation at the low profitability level, a highly positive correlation at the medium profitability level and a weak positive correlation at the high profitability level. Hence, we adopted the net profit rate of the banking industry and its quadratic as the core explanatory variables in Models 3-5 to conduct the panel fixed effect test. Due to the omission of variables and two-way causality, the endogenous problem was an empirical obstacle to studying the relationship between finance and the growth of the real economy. To address the endogenous issue, we adopted the dynamic panel GMM regression method and the explained variable with a lag of one order as the instrumental variable (IV). To further verify the robustness of the U-shaped relationship between the development of the banking industry and the real economy, we tested Models 6 and 7 through the dynamic panel GMM system using differential GMM and systematic GMM, with the net profit rate and its quadratic as the core explanatory variables. The results are summarized in Table 7.

Table 7 shows that the double threshold effect exists in both Model 1 that replaced the per capita real economic value added with the real economic value added and Model 2 that excluded the samples of western China and retained the samples of eastern and central China and manifests a negative correlation at the low level, a highly positive correlation at the medium level, and a weak positive correlation at the high level, which is consistent with the above regression results. Hence, the robustness of the conclusion has been verified.

We changed the estimation method and utilized the panel fixed effects to test the samples of the state, eastern China and central and western China. And the results show that Models 3-5 passed the significance test; the main explanatory variables and control variable coefficients were significant, and the coefficients of the quadratic terms of the banking industry's net profit rate were all positive, suggesting that there is a U-shaped nonlinear relationship with the explained variable, presenting a positive symbiotic relationship as a 
CPE

4,2

164

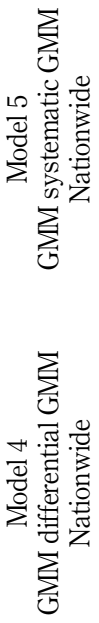

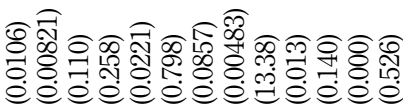

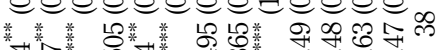

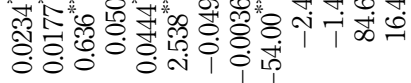

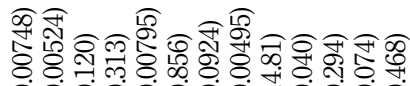

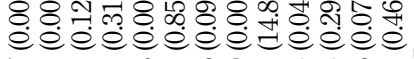

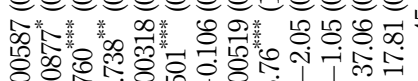

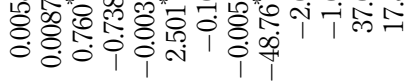

$\stackrel{\infty}{\approx} \quad \circ$

焉:

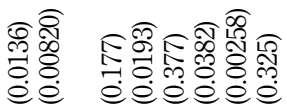

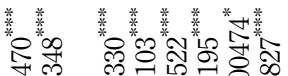

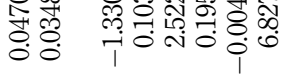

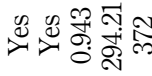

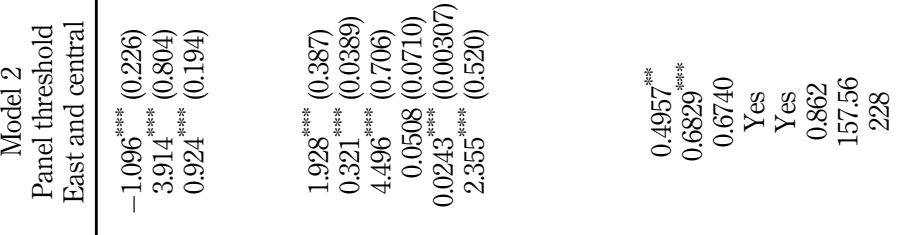

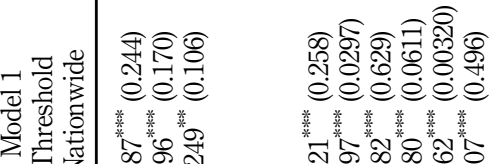

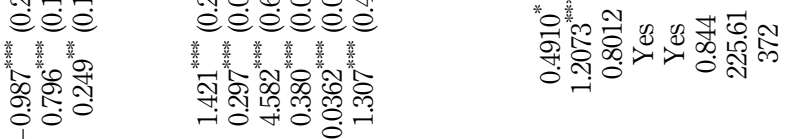

Table 7.

Robustness test results

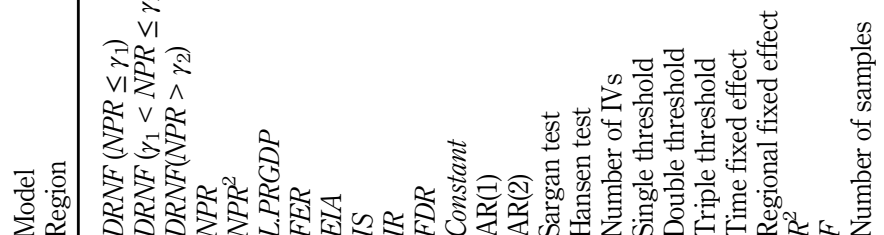


whole, but with dynamic changes in direction within different ranges - a negative correlation in the low profit rate range and a positive correlation in the high profit rate range, which is consistent with the above test findings based on the panel dual-threshold model, indicating the robustness of the test results.

After the dynamic panel estimation was introduced, both the differential GMM of Model 6 and the systematic GMM of Model 7 passed the Arellano-Bond AR (1) and AR(2) tests at the $5 \%$ level, indicating that the disturbance term has first-order self-correlation, and that there is no second-order self-correlation. The differential GMM passed the Sargan and Hansen instrumental variable over-identification tests, and the systematic GMM passed Hansen's instrumental variable overidentification test although it failed the Sargan test. In summary, the models have passed the self-correlation test and the IV validity test, and the estimation results by using differential GMM and systematic GMM are consistent and reliable. The results of both tests show that the coefficient of the quadratic term of the explanatory variable - the banking industry's net profit - is significant, evidencing the presence of the $U$-shaped relationship and proving the robustness of the threshold effect between the profitability of the banking industry and the growth of the real economy.

\section{Conclusions and recommendations}

Through literature review, theoretical analysis and factual analysis, this paper empirically tested the threshold relationship between bank profitability and economic growth based on the panel threshold model, with the results as follows: (1) Since the financial crisis in 2008, the profit growth of the banking industry and the growth of the real economy in China have shown consistent fluctuations as a whole, and with 2015 as the cut-off point, the relationship between them can be roughly divided into two different stages, showing a "scissors-shaped" trend. In the former stage, the profit growth rate of the banking industry continued to be higher than the growth rate of the real economy, whereas the opposite change occurred in the latter stage. (2) Compared with developed economies such as the USA, Japan and Germany, China's banking industry has a relatively high profit split to the real economy. In the major capital markets of the four countries, the ROE level of the banking industry in China's listed companies is generally higher than that of the real economy, which is in sharp contrast to that in the USA, Japan and Germany. (3) In the past decade or so, there has been a dual-threshold asymmetric relationship between the profitability of China's banking industry and the growth of China's real economy, with the threshold values of the banking industry's net profit rate being 0.491 and $0.801 \%$, respectively. In other words, when the banking industry's net profit rate is lower than $0.491 \%$, it will negatively affect the growth of the real economy; when the banking industry's net profit rate is between 0.491 and $0.801 \%$, it will have the optimal positive effect on the growth of the real economy; when the banking industry's net profit rate is higher than $0.801 \%$, its promotion effect on the growth of the real economy is reduced to a relatively low level, but no detrimental effect on the real economy due to the high level of banking profits is observed. Hence, we propose "three lines of defense" as follows:

\subsection{Establish a red line for the distribution rate of net profits for finance in industry at the macroeconomic level}

From the development process of the global financial sector and related historical lessons, it is necessary to establish a profit-sharing mechanism between the financial sector and the real economy to achieve the healthy and balanced development of real economy and finance. Measures should be taken to facilitate the financial sector to develop the major business of serving the real economy, incorporate the distribution rate of profits for the financial sector linked with the profits of the real economy into the macroprudential management assessment 
CPE

4,2

166
(MPA) of the central bank to ensure that the growth of financial profits is mostly consistent with local economic growth. Differences in industry-finance profit segmentation tolerance should be considered in the implementation process. The reform of the income distribution system should be deepened; the salary and remuneration in the financial sector should be controlled at a reasonable level through methods such as salary restriction and performance bonus deferral for financial practitioners to prevent excessive concentration of human resources in the financial sector. The establishment of a financial profit back-feeding mechanism should be explored, and the tax incentives, risk tolerance and other supporting measures in the Commercial Bank Performance Evaluation Measures should be improved to promote the establishment of a "dual-oriented" evaluation model for commercial banks with profitability as the goal and environmental and social responsibilities taken into account. At the current stage, it is necessary to fully exert the "head goose" effect of large banks regarding interest concessions, continue to make fee cuts and interest concessions to small and micro real-economy businesses, consider including fee cuts and interest concessions in the disclosure content of environmental and social governance reports of financial institutions and guide financial institutions to institutionalize fee cuts and interest concessions through public opinion, market assessments and checks by regulatory authorities.

\subsection{Establish a red line for market concentration at the mesoeconomic level}

In recent years, the market power resulting from administrative monopolies in the financial sector has declined considerably, but in general, financial monopolies still exist. The regional concentration measured by the Herfindahl index among regions has increased in the last two years [1], reflecting a decline in competition caused by regional administrative division and that financial resources show a tendency to concentrate in the eastern region. The Central Economic Work Conference 2020 pointed out that one of the focuses of economic work in 2021 should be anti-monopoly and preventing the disorderly expansion of capital. On the premise of maintaining financial stability, the barrier to the entry of the financial sector should be further relaxed, and innovative ways to remove barriers in the financial sector should be explored regarding the institutional mechanism. It is necessary to follow the new development pattern of "dual circulation", adhere to the opening-up internally and externally and drive the reasonable and free movement of financial capital between regions for enabling foreign and private capital with qualifications and risk prevention and control capabilities to enter the financial sector on an equal basis to supplement the capital of banks in central and western China and facilitate the balanced development of regional finance. The legal system for bankruptcy and reorganization of financial institutions should be improved, the innovation of regional economic integration in the financial field should be promoted, the high-quality financial resources in the regions should be coordinated and the merger and reorganization of small and medium-sized banking institutions should be accelerated to enhance the economies of scale. Encouraging large banks to accelerate digital transformation to improve the application efficiency of financial technology in inclusive and green finance and risk management and control, lower transaction costs and reduce diseconomies of scale. The problem that the monopolistic capital suppliers are detached from the real economy and have an adverse effect on the profitability structure of the real economy should be solved from the source.

\subsection{Establish a bottom line of profit rate at the microeconomic level}

A reasonable interest margin is the foundation for the survival of banking institutions. The banking industry should act rationally based on its capacity regarding interest concessions. Firstly, from the perspective of assets, attention should be paid to the heterogeneous and hierarchical promotion among different regions and institutions in the process of guiding the 
interest rate downward through LPR, considering the differences in cost of funds, governance level and risk control ability of different banks in different regions. Also, it is necessary to watch out for low-profit institutions making interest concessions blindly while suffering fund shortage, which is detrimental to the survival of banks, damages the development of the financial sector and ultimately increases the financing difficulties in the real economy. Second, from the perspective of liabilities, the supervision of chaos in the deposit market should be strengthened to keep a fair competition order and curb the irrational rise in the cost of debts of small and medium-sized banks. It is necessary to broaden the access of small and medium-sized banks to borrowing, increase policy-based fund replenishment and scientifically guide local financial departments, government agencies and state-owned enterprises in bidding for deposits for avoiding banks raising interest rates significantly to the limit and for reducing the burden of financial institutions in capital costs. To urge banking institutions to improve the rationality of cost of debts, strengthen internal fund transfer pricing management and prevent excessive development of high-risk, highincome asset businesses that undermine the sustainability of operations. Moreover, regions with severe fund shortages in the banking industry should accelerate the replenishment of capital from external sources to promote the internal replenishment of capital and help the financial sector enter a healthy state of symbiosis with the real economy as soon as possible.

\section{Note}

1. The Herfindahl index is a commonly used index to measure market concentration or competition. It is calculated based on the formula: $\mathrm{HI}=\sum(\mathrm{si} / \mathrm{S})^{2}$, where si is the total assets of the $\mathrm{i}$-th bank, and $\mathrm{S}$ is all banks. In this paper, banks are replaced by regions to calculate the Herfindahl index of regional dimensions. Since 2008, the Herfindahl index of 31 provinces or cities in China has generally presented a downward trend. However, after 2018, there has been a downward trend in regional banking competition, suggesting that the asset allocation of the banking industry has differentiated among regions.

\section{References}

Bagehot, W. (1873), Lombard Street: A Description of the Money Market, Scribner, Armstrong \& Company, New York.

Bakija, J., Cole, A. and Heim, B.T. (2012), "Jobs and income growth of top earners and the causes of changing income inequality", available at: http://web.williams.edu/Economics/wp/ BakijaColeHeimJobsIncomeGrowthTopEarners.pdf (accessed 17 September 2021).

Cecchetti, S.G. and Kharroubi, E. (2015), "Why does financial sector growth crowd out real economic growth?”, available at: https://www.bis.org/publ/work490.htm (accessed 17 September 2021).

Chen, K. and Zhao, X.J. (2012), "Zhongguo, deguo he meiguo shangye yinhang xiaolu chayi jiqi bijiao youshi fenxi [Analysis on the efficiency differences and comparative advantages of commercial banks in China, Germany and the United States]", Guoji jinrong yanjiu [Studies of International Finance], Vol. 29 No. 9, pp. 88-96.

Du, Y.F. (2008), "Quyu jinrong fazhan yu quyu jingji zengzhang-jiyu menxian moxing de shizheng fenxi [Regional financial development and regional economic growth — an empirical analysis on threshold model]", Jinrong lilun yu shijian [Financial Theory and Practice], Vol. 21 No. 10, pp. 33-35.

Fan, C.L., Zhang, Q.C. and Peng, M.S. (2021), "Jingji jinrong gongsheng gongrong: lilun, cedu yu shixian lujing [The symbiosis and mutual prosperity of economy and finance: theory, measurement and implementation path]", Xiandai caijing (Tianjin caijing daxue xuebao) [Modern Finance and Economics (Journal of Tianjin University of Finance and Economics)], Vol. 41 No. 1, pp. 3-17. 
CPE

4,2

Foley, D.K. (2013), "Rethinking financial capitalism and the 'information' economy", Review of Radical Political Economics, Vol. 45 No. 3, pp. 257-268.

Foroohar, R. (2016), Makers and Takers: The Rise of Finance and the Fall of American Business, Currency, New York.

Goldsmith, R.W. (1969), Financial Structure and Development, Yale University Press, New Haven.

Greenwood, J. and Smith, B.D. (1997), "Financial markets in development, and the development of financial markets", Journal of Economic Dynamics and Control, Vol. 21 No. 1, pp. 145-181.

Hansen, B.E. (2000), "Sample splitting and threshold estimation", Econometrica, Vol. 68 No. 3, pp. $575-603$.

Heblich, S. and Trew, A. (2019), "Banking and industrialization”, Journal of the European Economic Association, Vol. 17 No. 6, pp. 1753-1796.

Huang, Q.H. (2017), “Lun xinshidai zhongguo shiti jingji de fazhan [On the development of China's real economy at the new stage]", Zhongguo gongye jingji [China Industrial Economics], Vol. 34 No. 9, pp. 5-24.

Huang, Z.L. and Dong, Z.Y. (2013), "Woguo jinrong fazhan yu jingji zengzhang de feixianxing guanxi yanjiu-laizi dongtai mianban shuju menxian moxing de jingyan zhengju [Study on the nonlinear relationship between financial development and economic growth in China - empirical evidence from dynamic panel data threshold model]", Jinrong yanjiu [Journal of Financial Research], Vol. 36 No. 7, pp. 74-86.

Huang, H.C. and Lin, S.C. (2009), "Nonlinear finance-growth nexus: a threshold with instrumental variable approach", Economics of Transition and Institutional Change, Vol. 17 No. 3, pp. 439-466.

Jiang, R. and Liu, X.J. (2012), "Yinhang lirun dui jingji zengzhang yingxiang de shizheng fenxi-jiyu zhongmei liangguo shuju de duibi [An empirical analysis on bank profit and economic growth: analysis based on data of U.S. and China]", Guoji maoyi wenti [Journal of International Trade], Vol. 38 No. 5 , pp. $43-52$.

King, R.G. and Levine, R. (1993), "Finance and growth: Schumpeter might be right", Quarterly Journal of Economics, Vol. 108 No. 3, pp. 717-737.

Lapavitsas, C. (2013), Profiting Without Producing: How Finance Exploits Us All, Verso Books, London.

Law, S.H. and Singh, N. (2014), "Does too much finance harm economic growth?", Journal of Banking and Finance, Vol. 41 No. C, pp. 36-44.

Levine, R. (1991), "Stock markets, growth, and tax policy", Journal of Finance, Vol. 46 No. 4, pp. 1445-1465.

Li, X. and Chang, C. (2014), "Fei lixi yewu hui tisheng yinhang de jixiao ma?-jiyu PSTR moxing de feixianxing yingxiang shizheng jianyan [Does non-interest business improve banks' performance?-an empirical test based on nonlinear PSTR model]", Yuce [Forecasting], Vol. 33 No. 4, pp. 48-52.

Lin, J., Fan, C.L. and Cai, X.L. (2020), "Changsanjiao jinrong yitihua: shijian jixiao yu tuijin lujingjiyu yinhang xindai juhe shijiao [Financial integration in the Yangtze River Delta: practice, performance and promotion path-based on the perspective of bank credit aggregation]", Jianghai xuekan [Jianghai Academic Journal], Vol. 27 No. 2, pp. 89-97+254.

Liu, H. (2013), Liangci quanqiu daweiji de bijiao yanjiu [Comparative Study on the Two Global Crisis], China Economic Publishing House, Beijing.

Lvina, I.G. (2012), "The sources of financial profit: a theoretical and empirical investigation of the transformation of banking in the US", available at: https://scholarworks.umass.edu/cgi/viewcontent. cgi?article $=1617 \&$ context $=$ open_access_dissertations (accessed 17 September 2021).

Marx, K. (2004), Ziben lun: disanjuan [Das Kapital: Volume III] (Chinese translation edition translated by Central Compilation and Translation Bureau), People's Publishing House, Beijing, p. 415. 
Mavroudeas, S. (2018), "The financialisation hypothesis and Marxism: a positive contribution or a Trojan horse?". available at: https://www.counterpunch.org/2018/05/11/the-financialisationhypothesis-and-marxism-a-positive-contribution-or-a-trojan-horse/ (accessed 17 September 2021).

Piketty, T. (2014), Das Kapital im 21. Jahrhundert, C.H. Beck, Munich.

Schumpeter, J.A. (1982), The Theory of Economic Development: An Inquiry into Profits, Capital, Credit, Interest, and the Business Cycle (1912/1934), Transaction Publishers, New Jersey, p. 244.

Shaw, E.S. (1973), Financial Deepening in Economic Development, Oxford University Press, New York.

Smith, R., Staikouras, C. and Wood, G. (2003), "Non-interest income and total income stability", available at: https://papers.ssrn.com/sol3/papers.cfm?abstract_id=530687 (accessed 17 September 2021).

Wang, H.H. and Pan, Y. (2018), "Jinrong fazhan dui chanye shengji yingxiang de feixianxing xiaoying-jiyu jingjinji he changsanjiao diqu chengshiqun de bijiao fenxi [Nonlinear effects of financial development on industrial upgrading: a comparative analysis of Yangtze River Delta region and Beijing-Tianjin-Hebei urban agglomeration]", Jingji dili [Economic Geography], Vol. 38 No. 9, pp. 59-66.

Wen, S.Y., Mou, S. and Liu, X.L. (2020), "Zhongguo jinrongye lirun guogao lema-jiyu makesi shengxi ziben lilun de fenxi yu shizheng zhengju [Is the profit of the financial industry in China too high? - analysis based on Marx's interest-bearing capital theory and empirical evidence]", Jingjixuejia [Economist], Vol. 32 No. 6, pp. 95-106.

Wu, J., Yang, G. and Li, R. (2018), "Zhongguo yinhangye gaolirun de helixing bianxi [Analysis on the rationality of high profits in Chinese banking sector]", Hebei jingmao daxue xuebao [Journal of Hebei University of Economics and Trade], Vol. 39 No. 2, pp. 26-33.

Xing, T.C., Sun, J. and Yan, L.L. (2013), "Jingji zhouqi zhanlue dui shangye yinhang yingli nengli de yingxiang [The impact of business cycle strategies on profitability of commercial banks]", Guoji jinrong yanjiu [Studies of International Finance], Vol. 30 No. 5, pp. 88-96.

Zhang, J. and Wu, D. (2013), "Yinhang yu qiye de guanxi: gongsheng yihuo lueduo [The relationship between bank and enterprise: symbolic or grabbing]", Jingji lilun yu jingji guanli [Economic Theory and Business Management], Vol. 33 No. 6, pp. 77-90.

Zhao, Z.Q., Yu, Z. and Yang, D.L. (2007), "Jinrong fazhan yu jingji zengzhang de feixianxing guanlian yanjiu-jiyu menxian moxing de shizheng jianyan [The nonlinear relationship between financial development and economic growth: evidence from threshold methodology]", Shuliang jingji jishu jingji yanjiu [The Journal of Quantitative and Technical Economics], Vol. 24 No. 7, pp. 54-62.

\section{About the authors}

Conglai Fan, Director of the Yangtze River Delta Economics and Social Development Research Center of Nanjing University, distinguished professor of MOE Changjiang Scholars Program, professor at the Business School of NJU. Conglai Fan is the corresponding author and can be contacted at: fancl@nju. edu.cn

Xinlei Cai, Ph.D. student at the Yangtze River Delta Economics and Social Development Research Center of Nanjing University.

Jian Lin, Ph.D. student at the Yangtze River Delta Economics and Social Development Research Center of Nanjing University.

For instructions on how to order reprints of this article, please visit our website:

www.emeraldgrouppublishing.com/licensing/reprints.htm

Or contact us for further details: permissions@emeraldinsight.com 